\title{
SPECIFICATIONS OF NUTRITION WITH HEALTHY AND PATHOLOGICAL CONDITIONS OF PSORIASIS
}

\author{
Nurgozhina A. ${ }^{2}$, Yermekbayeva B. ${ }^{1}$, Gulyayev A. ${ }^{2}$, Kozhakhmetov S. ${ }^{2}$, Sergazy Sh. ${ }^{2}$, \\ Nurgaziyev M. ${ }^{2}$, Aitenov Y. ${ }^{2}$, Chulenbayeva L. ${ }^{2}$, Tuyakova A. ${ }^{2}$, Kushugulova A. ${ }^{2}$ \\ ${ }^{1}$ University Medical Center, \\ 53, Kabanbay batyr ave., Nur-Sultan, 010000, Kazakhstan \\ ${ }^{2}$ Laboratory of Human Microbiome and longevity, Center for life sciences, National \\ Laboratory Astana, Nazarbayev University, Nur-Sultan, Kazakhstan \\ anurgozhina@nu.edu.kz.
}

\begin{abstract}
Psoriasis is a long-lasting autoimmune disease characterized by patches of abnormal skin. 183 participants in the experiment were selected for the study, half of which are with psoriasis disease. All participants in the study passed the EPIC-Norfolk Food Frequency Questionnaire, which was completed once and included a diet over the past week. The aim of the study was to identify the intakes of different nutrients in two groups by age. After questionnaire FETA tool was used to analyze all answers (http://www.srl.cam.ac.uk/epic/epicffq/). The output was the results for all nutrients and macro and microelements that are in the food. Significant differences in patients were in eight nutrients, namely: betacarotene, carotene, fructose, potassium, potatoes, fruits, nuts and seeds, and vegetables. All differences are in favor of healthy patients. Patients with psoriasis had a diet with low income of fruits and vegetables which brought to the deficiency in some nutrients and vitamins. The used tool for converting food frequency questionnaire data into nutrient and food group values can be used widely for different study populations.
\end{abstract}

Keywords: nutrition, psoriasis, food frequency questionnaire

\section{INTRODUCTION}

Psoriasis is a long-lasting autoimmune disease characterized by patches of abnormal skin. The prevalence of psoriasis is about $2 \%$ worldwide, differing by regions [1]. Psoriasis is a multisystem inflammatory disease with predominantly skin and joint involvement which affects both sexes equally. In addition to the physical changes of the skin, psoriasis also has an emotional and psychosocial effect on the patient [2]. There is a key role of nutritional factors in the development of psoriasis. Recently, modern literature has been actively discussing the role of nutrition as a predictor of the development of psoriasis and its effect on the course of psoriasis. The publications analyzed the positive effect of the correction of metabolic disorders on skin processes in patients with psoriasis. The role of food allergy and gastrointestinal tract pathology in the etiopathogenesis of psoriatic disease and the intolerance of certain foods in the development of psoriasis are evaluated. It is believed that food allergy is a reflection of the 
systemic dermatological and gastrointestinal process and is manifested by psoriatic skin rashes [3]. The relationship between adherence to the Mediterranean diet and the severity of psoriasis is described in great detail [4]. The nature of nutrition and various diets play a significant role in the etiopathogenesis of psoriasis and this must be taken into account with standard therapy. The aim of the article was to evaluate and compare the diets of healthy patients and patients with psoriasis using a questionnaire. The hypothesis of our research was that diet becomes an important adjunct to current treatments of psoriasis.

\section{Materials and methods}

91 patients with mild to moderate vulgar psoriasis in the progression stage of the process (main group) and 92 healthy volunteers (control group) participated in the survey. The questionnaire for identifying anamnestic data and assessing the frequency of food intake according to the EPIC-Norfolk Food Frequency Questionnaire. The main questions of the questionnaire included: gender identification, age of patients, clinical diagnosis, the debut of the disease, heredity, seasonality, information about concomitant diseases and trigger factors. Nutrition questions related to all food preferences, daily consumption of fruits, drinks, dairy products, etc. (120 food items). This part of the questionnaire made it possible to identify the hierarchy of nutrients that affect the risk of psoriasis. A clinical assessment of the severity of psoriasis patients, scored from 0 to 72, was performed using the PASI (Psoriasis Area Severity Index) [5] prevalence and severity index, which is the gold standard and includes the assessment of objective signs of the disease (erythema, peeling intensity and infiltration), taking into account the intensity of manifestations of clinical signs. All questions regarding gluten, milk, meat, vegetables and fruits products were analyzed using the frequency of consumption. Each answer covered from "not at all" to "almost every day" answer. Z score model was used to see the difference between healthy and group with psoriasis depending on a specific food. For multivariate differences between the groups, PCA biplots have been built on centered and scaled data. To assess the features that are different between the control and disease groups two-tailed ttest has been performed. The study was approved by the local ethical committee of the Astana Medical University and registered on clinicaltrials.gov as identifier number: NCT03594877. Psoriasis patients and healthy volunteers were included in the study after signing informed consent. FETA software was used for analysis questionnaire and after taking all results data were analyzed using $\mathrm{R}$ studio 3.6 .2 version program. Data were expressed as the mean \pm standard deviation and a p-value $<0.05$ was considered to be statistically significant.

\section{RESULTS}

As part of our study, a clinical and laboratory examination of patients with psoriasis $(\mathrm{n}=$ 91) of mild to moderate severity was performed. The main group of participants studied was 52 men $(57.1 \%)$ and 39 women (42.9\%), with average age of $36.6 \pm 4.1$ years. The control group consisted of 92 healthy volunteers, the average age of which was $36.1 \pm 3.8$ years, with an equal number of male and female participants. In addition to gender and age structure, while studying the composition of research groups, other parameters were analyzed, including the level of education.

According to the questionnaire, the family status of the subjects was the following: 60 people $(65.9 \%)$ in the main group in the marriage, 74 people in the control group $(80.4 \%)$. For 
unspecified (for ethical reasons) reasons, unmarried subjects of the main group amounted to $34.1 \%$ (31 people), of the control group - 19.6\% (18 people). The difference in the criterion of marital status between the groups turned out to be statistically significant, as patients with psoriasis were much less likely to marry compared to the control group $(\mathrm{p}=0.041)$.

The overwhelming majority of psoriasis duration (85.7\% - 78 people) exceeded 5 years, including in $44.0 \%$ (40) of the respondents the duration of the disease varied from 5 to 10 years, in $41.8 \%$ (38) cases the first signs of psoriasis appeared more than 10 years ago, and in $14.2 \%$ the manifestation of the disease did not exceed 2 years. When distributing patients according to the severity of psoriasis, depending on the PASI score, a low score corresponding to the mild course was found in $46.2 \%$ (42) cases, and a median score corresponding to the moderate severity of psoriasis was found in $53.8 \%$ (49) patients.

As a result, it was found that in the group of patients with psoriasis people with a higher education prevailed - their share was $59.3 \%$ (54), while the share of people with secondary education was less $-40.7 \%$ ( 37 people). In the control group, the presence of higher education was recorded in more than half $-63.0 \%$ (58 people), while secondary education - only $37.0 \%$ (34).

In 183 patients, after analysis of all nutrients and micronutrients, the following changes were found. Significant differences in patients were in eight nutrients, namely: beta-carotene, carotene, fructose, potassium, potatoes, fruits, nuts and seeds, and vegetables (Figure 1). All differences are in favor of healthy patients. Of all the significant changes, vegetables show the greatest differences along with fruits. 

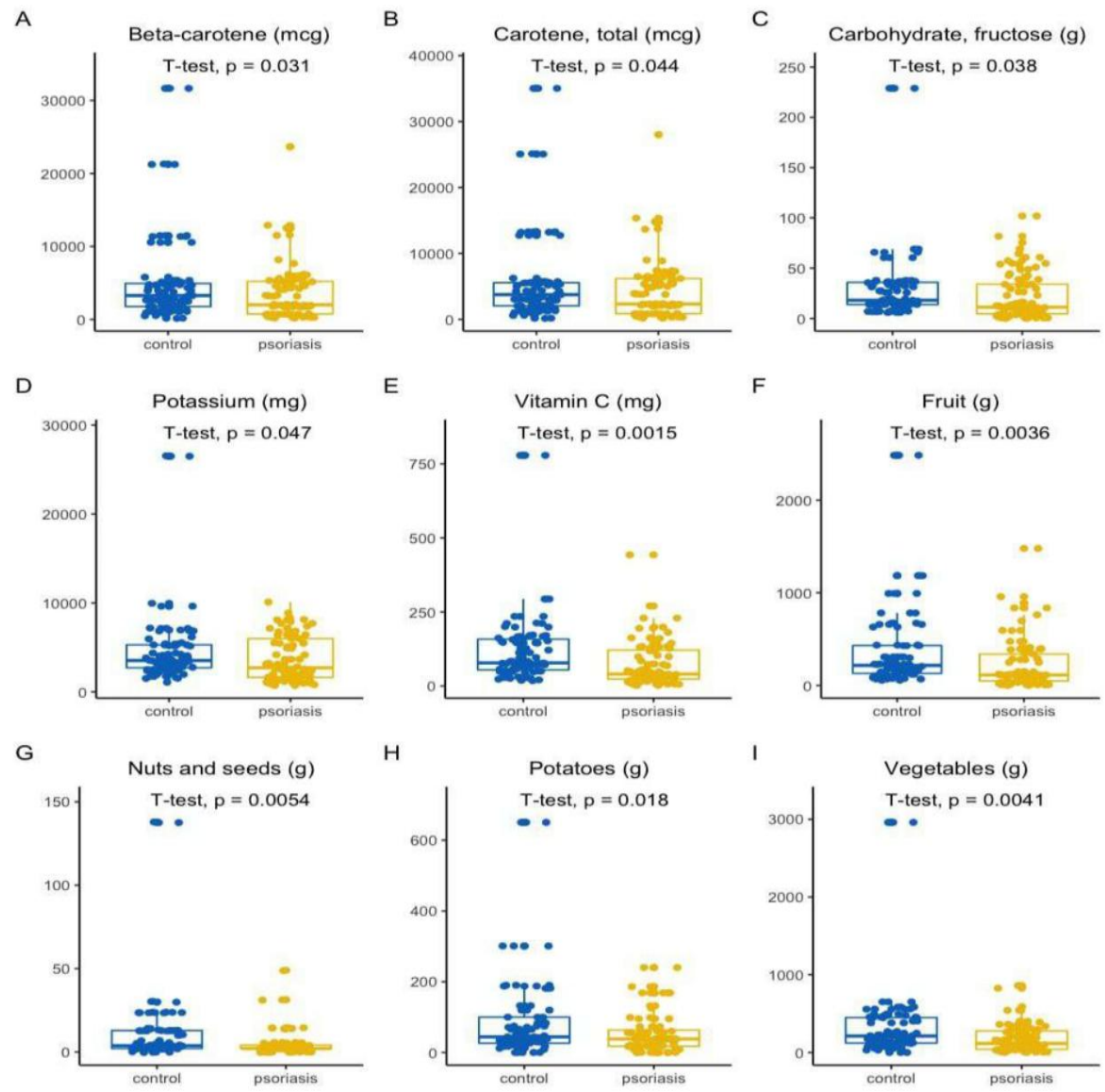

A - beta-carotene, B - carotene, C - carbohydrate fructose, D - potassium, E - vitamin C, F - fruits, G - nuts and seeds, H - potatoes, I - vegetables

Fig. 1. Eight main categories including nutrients and food which had a significant difference in two groups ( $\mathrm{p}$ value $<0,05)$

Using information about each product, we qualified products for different subgroups such as vegetables, fruits, milk products, meat and gluten products. $65.3 \%$ of patients with psoriasis and $41.3 \%$ of healthy patients rarely eat fruit. $34.5 \%$ of respondents with psoriasis and $58.7 \%$ of healthy respondents said they eat fruit every day and several times a day. The same results were shown by patients in the consumption of vegetables. Namely, $17.4 \%$ more healthy patients than patients with psoriasis eat vegetables every day.

PCA has been performed on the output of FETA tool. PC1 and PC2 have contributed to $77 \%$ and $4.9 \%$ of the total variation respectively; however, no visual separation of the two groups was evident. Moreover, the values of PC1 loadings did not exceed 0.15 and therefore considered low and unsuitable for further analysis. Cumulative variance plot has revealed that 
PCA needed 8 components to capture 95 of the variance (Figure 2).

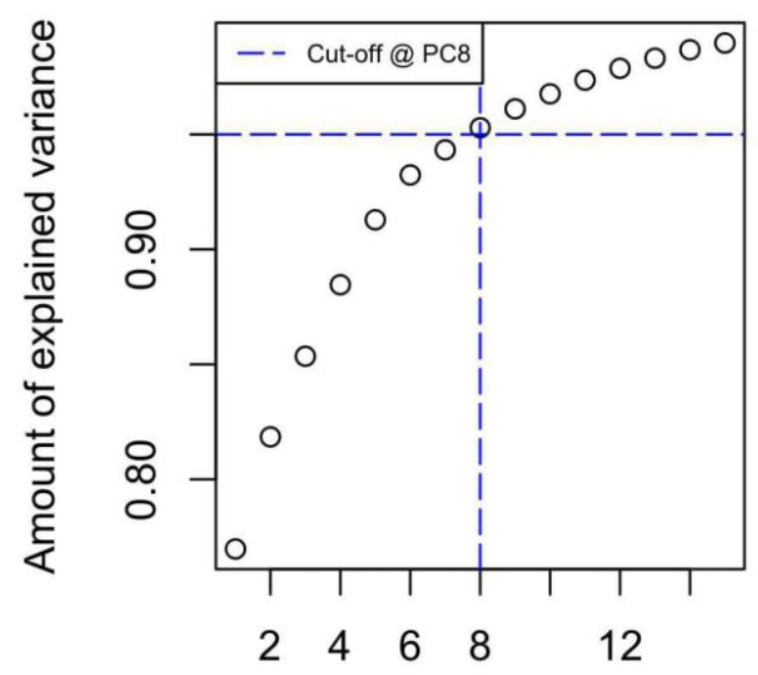

PC \#

Fig. 2. Cumulative variance scatterplot showing a cut-off at PC 8 where $95 \%$ of variance in FETA tool output data on patient dietary habits is explained. Each dot represents a calculated principal component (PC1-PC15).

In order to maximize the component axes for better separation, we run an LDA classifier on PCA-transformed data. As a result, the ROC plot (Figure 3) revealed a successful model with $\mathrm{AUC}=0.741$, which can be used to distinguish between healthy and psoriasis patients. 


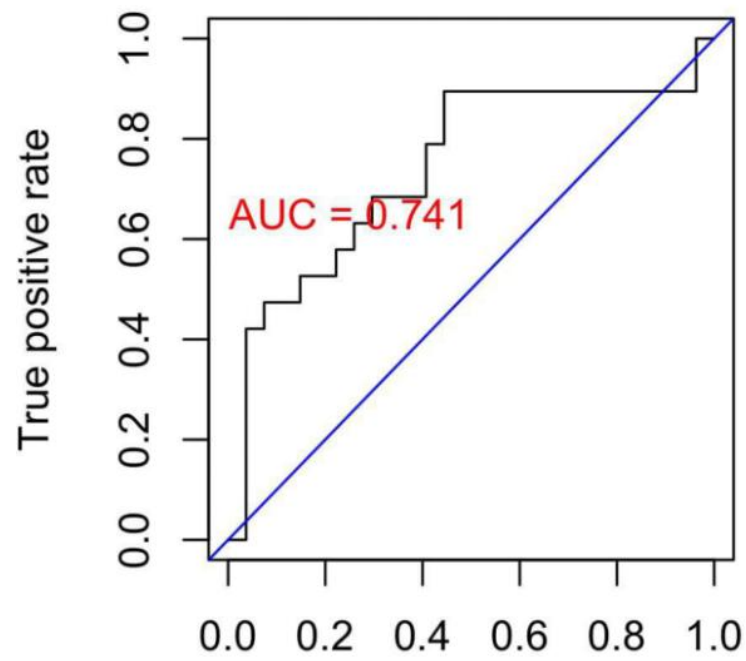

False positive rate

Fig. 3. ROC plot built on PCA-transformed LDA model showing the validity of the dietary questionnaire data for binary classification of healthy and psoriasis patients. AUC value is shown in red.

\section{DISCUSSION}

In the framework of the study, in accordance with the objectives, using the adapted international Food Frequency Questionnaire, we analyzed the nature of nutrition in the main and control groups. There were no statistically significant differences in the total daily caloric intake and consumption of the main nutrients between the two groups. These data are consistent with the results of a number of studies elsewhere in the world - in works where the complex characteristics of the diet of patients with psoriasis were studied, no differences with healthy individuals were found [6].

The results are consistent with data from other researchers who noted the influence of socio-economic factors (including educational level) on the occurrence and course of psoriasis. Moreover, these factors influenced the prognosis, severity and adequacy of psoriasis treatment, rather than the incidence in general [6]. Some authors explain the relationship between the level of education and the severity of psoriasis with the possible influence of the former on the choice of foods and overall eating behavior [7].

The anthropometric criterion, namely the body mass index (BMI), among the entire sample of subjects was $24.5 \pm 3.6 \mathrm{~kg} / \mathrm{m}^{2}$. The average body mass index in the main group was $25.1 \pm 3.7$ $\mathrm{kg} / \mathrm{m}^{2}$, in the control group $-24.0 \pm 3.6 \mathrm{~kg} / \mathrm{m}^{2}$. BMI, according to the results of our study, was practically comparable in both groups. Since BMI of psoriasis patients in our study did not indicate the presence of obesity, but was at the extreme border of normal indicators, one of the most important goals in the treatment of psoriasis and the prevention of its complications should be monitoring the weight of patients and a low-calorie diet [8]. 
When analyzing the volume of consumption of individual food products in the study groups, it was found that patients in the subgroup with mild psoriasis, in comparison with the control group, consumed significantly fewer fruits $(\mathrm{p}=0,0003)$, vegetables $(\mathrm{p}=0,0079)$. Analyzing the diet in patients with psoriasis, we can conclude that there is an extremely small amount of vegetables and fruits in food consumed.

Therefore, taking into account the statistically significant differences between the consumption of certain food products by the main and control groups, it can be concluded that patients with psoriasis have an unbalanced diet and insufficient nutritional status, especially in the consumption of fish and plant products. As a result, they lack vitamins and minerals, which are so necessary for the normal functioning of the body in general, as well as the skin and its derivatives in particular, which can also be considered as a risk factor for the development and exacerbation of the course of the disease. A similar hypothesis was expressed earlier by some foreign authors [10]. Of course, we agree with the opinion of researchers [11] that fruits and vegetables containing polyphenols with recognized antioxidant ability can participate in nutrigenomic reprogramming and have a beneficial effect on the pro-inflammatory status in psoriasis. But we suggest taking into account that in some situations the role of vegetables in psoriasis can also be negative. For example, some researchers describe [3] an increase in the frequency of occurrence of a high concentration of specific IgE to potato and carrot allergens in patients with psoriasis is noted, which most likely reflects cross-reactions with pollen allergens. More detailed prospective clinical studies should clarify the positive and negative aspects of the diet for psoriasis. Our results support the previously formed idea that interventions in the stereotype of nutrition and lifestyle are a promising treatment for psoriasis and its associated comorbidities. However, gaps and inadequacies exist within the literature, e.g. methodology, absence of a unified scoring system, lack of controlled clinical data and future directions should focus on high-quality cohort studies and clinical trials. It was also convincingly shown that patients with the mild and moderate clinical course of psoriasis consumed significantly more often products that have the greatest effect on the exacerbation of psoriasis. Our results support the previously formed idea that interventions in the stereotype of nutrition and lifestyle are a promising treatment for psoriasis and its associated co-morbidities. However, gaps and inadequacies exist within the literature, e.g. methodology; absence of a unified scoring system, lack of controlled clinical data and future directions should focus on high-quality cohort studies and clinical trials.

\section{CONCLUSION}

To conclude, patients with psoriasis had a diet with low income of fruits and vegetables which brought to the deficiency in some nutrients and vitamins mentioned above. There are some limitations of the research such as filling the survey. It was taken only once and all participants filled the form by themselves. It could lead to biased answering the questions. Further research can be done by taking several questionnaires for example food diary method or 24-hour recall to make a comparison of each other and find the most suitable for our population. One more aspect is the absence of Kazakh traditional food in the questionnaire, for example, horse meat and milk and others. Further study could be done using questions with Kazakh traditional food. For this, all data about each product should be inserted into the software for analysis of the survey. 


\section{Acknowledgements}

This work was supported by the Ministry Education and Science of the Republic of Kazakhstan (grant № AP05135585 «The development of auxiliary methods of therapy of psoriasis depending on a structure of a microbiome»).

\section{REFERENCES}

1. Christophers, E. Psoriasis epidemiology and clinical spectrum Clin Exp Dermatol., 2001, vol. 26 , no.4, pp. 314-320

2. Levine, D., Gottlieb, A. Evaluation and management of psoriasis: an internist's guide. Med Clin North Am., 2009, vol.93, no.6, pp.1291-1303

3. Barilo, A., Smirnova, S. The role of alimentary factors and food allergies in the development of psoriasis. Vopr Pitan., 2020, vol.89, no.1, pp. 19-27

4. Barrea, L., Balato, N., Di Somma, C., et al. Nutrition and psoriasis: is there any association between the severity of the disease and adherence to the Mediterranean diet? J Transl Med., 2015, vol.13, no.18, pp. 1-10

5. Kubanov, A., Karamova, A., Znamenskaya, L., et al. PASI (Psoriasis Area and Severity Index) in the evaluation of the clinical manifestations of psoriasis. Vestnik dermatologii I venerologii, 2016, vol. 92, no. 4, pp. 33-38

6. Bardazzi, F., Tengattini, V., Rucci, P., et al. Socio-economic status and severity of plaque psoriasis: a cross-sectional study in the metropolitan city of Bologna. Eur J Dermatol, 2019, vol.29, no. 2, pp. 197-202

7. Mahé, Emmanuel et al. Socioeconomic Inequalities and Severity of Plaque Psoriasis at a First Consultation in Dermatology Centers. Acta dermato-venereologica, 2017, vol.97, no. 5, pp.632-638

8. Snekvik I., Smith C., Nilsen T., et al. Obesity, Waist Circumference, Weight Change, and Risk of Incident Psoriasis: Prospective Data from the HUNT. J Invest Dermatol, 2017, vol.137, no.12, pp.2484-2490

9. Barrea, L., Nappi, F., Di Somma, C., et al. Environmental Risk Factors in Psoriasis: The Point of View of the Nutritionist. Int J Environ Res Public Health, 2016, vol.13, no.5, pp. 743

10. Sims, J., Smith, D. The IL-1 family: regulators of immunity. Nat Rev Immunol., 2010, vol.10, no.2, pp. 89-102

11. Kocic, H., Damiani, G., Stamenkovic, B., et al. Dietary compounds as potential modulators of microRNA expression in psoriasis. Ther Adv Chronic Dis., 2019, vol.10, pp. $1-13$ 


\title{
ДЕНІ САУ ЖӘНЕ ПСОРИАЗДЫН ПАТОЛОГИЯЛЫК ЖАҒДАЙЫ БАР ПАЦИЕНТТЕРДІН ТАМАҚТАНУ ЕРЕКШЕЛІКТЕРІ
}

\author{
Нургожина А. ${ }^{2}$, Ермекбаева Б. ${ }^{1}$, Гуляев А. ${ }^{2}$, Кожахметов С. ${ }^{2}$, Сергазы Ш. \\ Нургазиев М. ${ }^{2}$, АйтеновЕ. ${ }^{2}$, Чуленбаева Л. ${ }^{2}$, Туякова А. ${ }^{2}$, Кушугулова А. ${ }^{2}$ \\ 1 "University Medical Center" корпоративтік қ̧оры \\ 2 Адам микробиомы және ұзақ өмір сүру зертханасы, Өмір тураль выльмдар \\ ортальвы, National Laboratory Astana, Назарбаев Университеті \\ Қабанбай батыр данув. 53 Нұр-сұлтан, 010000, Қазақсттан \\ anurgozhina@nu.edu.kz
}

\section{ТYЙІН}

Псориаз-бұл терінің өзгеруімен сипатталатын ұзақ аутоиммундық ауру. Зерттеу үшін экспериментке 183 қатысушысы таңдалды, олардың жартысы псориазбен ауырады. Зерттеудің барлық қатысушылары EPIC-Norfolk сауалнамасынан өтті, ол бір рет толтырылып, өткен аптадағы тамақтану диетасын қамтыды. Зерттеудің мақсаты екі топтағы әртүрлі қоректік заттарды тұтынуды анықтау болды. Сауалнамадан кейін барлық жауаптарды талдау үшін FETA құралы қолданылды (http://www.srl.cam.ac.uk/epic/epicffq/). Нәтижесі тамақ құрамындағы барлық қоректік заттар, макро және микроэлементтер болды. Науқастарда сегіз қоректік заттар, атап айтқанда бета-каротин, каротин, фруктоза, калий, картоп, жемістер, жаңғақтар мен тұқымдар, сондай-ақ көкөністер бойынша айтарлықтай айырмашылықтар болды. Барлық айырмашылықтар сау пациенттердің пайдасына. Псориазбен ауыратын науқастар жемістер мен көкөністердің аз мөлшерін тамақтанды, бұл кейбір қоректік заттар мен дәрумендердің жетіспеушілігіне әкелді. Тамақтану жиілігі туралы сауалнама деректерін қоректік заттар мен тамақ топтарының құндылықтарына айналдыру үшін қолданылатын құрал әртүрлі зерттелген топтар үшін кеңінен қолданыла алады.

Негізгі сөздер: тамақтану, псориаз, тамақтану жиілігінің сауалнамасы

\section{ОСОБЕННОСТИ ПИТАНИЯ У ЗДОРОВЫХ ПАЦИЕНТОВ И С ПАТОЛОГИЧЕСКИМ СОСТОЯНИЕМ ПСОРИАЗА}

\author{
Нургожина А. ${ }^{2}$, Ермекбаева Б. ${ }^{1}$, Гуляев А. ${ }^{2}$, Кожахметов С. ${ }^{2}$, Сергазы Ш. \\ Нургазиев М. ${ }^{2}$, Айтенов Е. ${ }^{2}$, Чуленбаева Л. ${ }^{2}$, Туякова А. ${ }^{2}$, Кушугулова А. ${ }^{2}$ \\ ${ }^{1}$ Корпоративный фонд «University Medical Center», Нур-Султан, Казахстан \\ ${ }^{2}$ Лаборатория микробиома человека и долголетия, Центр наук о жизни, National \\ Laboratory Astana, Назарбаев Университет \\ Кабанбай батыра просn. 53, Нур-Султан, 010000 Казахстан \\ anurgozhina@nu.edu.kz
}

\section{АБСТРАКТ}


Псориаз - длительное аутоиммунное заболевание, характеризующееся участками кожи с изменениями. Для исследования было отобрано 183 участника эксперимента, половина из которых больны псориазом. Все участники исследования прошли анкету EPIC-Norfolk по частоте приема пищи, которая заполнялась один раз и включала диету на прошлой неделе. Целью исследования было выявить потребление различных питательных веществ в двух группах. После анкетирования был использован инструмент FETA для анализа всех ответов (http://www.srl.cam.ac.uk/epic/epicffq/). На выходе были результаты для всех питательных веществ, макро и микроэлементов, содержащихся в пище. Существенные различия у пациентов были по восьми питательным веществам, а именно: бета-каротину, каротину, фруктозе, калию, картофелю, фруктам, орехам и семенам, а также овощам. Все отличия в пользу здоровых пациентов. Больные псориазом придерживались диеты с низким содержанием фруктов и овощей, что приводило к дефициту некоторых питательных веществ и витаминов. Используемый инструмент для преобразования данных вопросника о частоте приема пищи в значения питательных веществ и пищевых групп может широко использоваться для различных исследуемых групп.

Ключевые слова: питание, псориаз, опросник частоты приема пищи 